Article

\title{
The Effects of Edaphic and Climatic Factors on Secondary Lichen Chemistry: A Case Study Using Saxicolous Lichens
}

\author{
Alexander Paukov ${ }^{1, *}$, Anzhelika Teptina ${ }^{1}$, Maria Morozova ${ }^{1}$, Ekaterina Kruglova ${ }^{1}$, \\ Sergio E. Favero-Longo ${ }^{2}$, Cora Bishop ${ }^{3}$ and Nishanta Rajakaruna ${ }^{3,4}$ (i) \\ 1 Institute of Natural Sciences and Mathematics, Ural Federal University, Lenina av. 51, 620000 Ekaterinburg, \\ Russia; ateptina@gmail.com (A.T.); morphey_usu@mail.ru (M.M.); kruglovaep@mail.ru (E.K.) \\ 2 Dipartimento di Scienze della Vita e Biologia dei Sistemi, Universitá degli Studi di Torino, Viale Mattioli 25, \\ 10125 Turin, Italy; sergio.favero@unito.it \\ 3 Biological Sciences Department, California Polytechnic State University, San Luis Obispo, CA 93407, USA; \\ cobishop@calpoly.edu (C.B.); nrajakar@calpoly.edu (N.R.) \\ 4 Unit for Environmental Sciences and Management, North-West University, Private Bag X6001, \\ Potchefstroom 2520, South Africa \\ * Correspondence: alexander.paukov@urfu.ru
}

Received: 15 May 2019; Accepted: 14 June 2019; Published: 17 June 2019

\begin{abstract}
Diversity of secondary lichen metabolites and their relationship to substrate and environmental parameters were studied in saxicolous lichens in the Middle and South Urals of Russia. Atranorin, usnic acid, gyrophoric acid, zeorin, norstictic acid, antraquinones and stictic acid were found in 73, 42, 41, 37, 36, 35 and 32 species, respectively, of 543 taxa collected. One hundred and ninety six species (i.e., $36 \%$ of total species documented) contained no secondary metabolites. Spectra of secondary metabolites of crustose lichens varied on different rock types, while in fruticose and foliose groups only those species without lichen acids were dependent on the substrate type. In Canonical Correspondence Analysis, secondary lichen metabolites were subdivided into groups depending on the concentration of $\mathrm{Ca}$ and metals in the substrate. Gyrophoric, lobaric, psoromic, rhizocarpic and stictic acids were common in crustose lichens in metal-poor habitats; species with antraquinones and lichens without any secondary metabolites were most abundant on limestone (alkalic and metal-poor), while other common lichen metabolites had no to minimal dependence on the chemistry of the substrate. The two additional abiotic factors affecting the composition of secondary metabolites were the maximum temperature of the warmest month and elevation. Our results suggest a range of possible relationships exist among lichen acids, rocks and climatic parameters. Furthermore, the same metabolite may affect both accumulation of metals and stress tolerance under unfavorable conditions.
\end{abstract}

Keywords: saxicolous lichens; lichen acids; rock chemistry; climatic factors; Urals; CCA

\section{Introduction}

Lichens produce a wide range of secondary metabolites, often collectively referred to as 'lichen acids,' only a few of which are present in other organisms [1]. More than 800 lichen acids are currently known, and more are being discovered on a regular basis [2]. Lichen secondary metabolites, including pigments, have a number of known functions. Some substances are biologically active and act as allelopathic agents $[3,4]$, while others affect herbivore palatability [5,6], increase permeability of the cell membrane of phycobionts [7,8] and protect photobionts from excessive ultraviolet (UV)-B light [3,6-11]. 
Environmental conditions strongly affect both the type and the concentration of secondary metabolites in lichens. Concentrations of melanins and anthraquinones vary depending on the amount of UV-B light; the mycobiont is presumed to be the more susceptible partner to such variations, compared to the algal component [12]. Usnic and fatty acids are found to decrease in concentration with increased levels of anthropogenic stress while the rising levels of salazinic acid in lichens in ozone-enriched environments likely provide a protective function [13]. Lichen substances also have antioxidant properties which are beneficial in high latitudes where reactive oxygen species are formed under both high UV-B levels and prolonged winter darkness [14,15]. However, the relationship among pigment concentration in thalli, habitat conditions and lichen growth patterns is complex [16]; for example, the same lichen species can show different physiological responses to UV-B light based on growing season and habitat conditions [17] and additional studies are required to demonstrate how lichens and their secondary metabolites respond to enhanced UV-B radiation and other aspects of global climate change or local habitat conditions.

Environmental conditions such as water availability, solar radiation and temperature may cause the appearance of chemosyndromes in species. Chemical changes in Ramalina cuspidata (Ach.) Nyl. and R. siliquosa (Huds.) A.L. Sm. are likely affected by an evapotranspiration gradient [18]. Additionally, another pair of morphologically indistinguishable but chemically distinct Ramalina species is subdivided in their geographical distributional range [19]. Variability of secondary metabolites within the chemospecies of Cladonia chlorophaea-group is also attributed to physiography [20]. Phycosymbiodeme pairs-morphotypes of a species differing in their photobionts-which are also largely controlled by the habitat microclimate, often contain different secondary metabolites [21,22].

The substrate type and its properties have a paramount importance for lichens and may prevail over the microclimatic factors. Physical parameters of the substrate, the microtopography of the surface, $\mathrm{pH}$, elemental content and surface availability for colonization are among the factors which affect lichen diversity as well as the structure of saxicolous lichen communities [23-30]. The wide range of rocks as a substrate for lichens and associated lichen metabolites imply a multitude of interactions among them. Lichen acids affect the acidity tolerance of lichens and, thus, the choice of their substrate [31]. Species of the same genus containing different metabolites dominate on different types of rocks [27] and a spectrum of chemical constituents of lichens have been shown to gradually change from quartzite to limestone [32].

Secondary lichen metabolites interact with metals in the substrate. Although lichen deterioration of rocks is often related to the secretion of primary metabolites such as oxalic acid [33-35], lichen secondary metabolites were also shown to act as chelating agents, promoting the absorbance of $\mathrm{Cu}$, $\mathrm{Fe}, \mathrm{Mg}, \mathrm{Mn}, \mathrm{Ni}$ and $\mathrm{Zn}$ and inactivating potentially toxic elements in thalli [36-41]. By facilitating the absorption of metals, lichen acids contribute to mineral nutrition of thalli which is essential in impoverished environments [42,43]. In contrast, lichens on metal (Fe)-rich rocks or slags were shown to be mostly devoid of secondary metabolites or containing secondary metabolites which decrease $\mathrm{Me}(\mathrm{Fe})^{2+}$ adsorption, explaining their tolerance of excessive concentrations [39]. Lichens may even reduce the relative concentrations of secondary metabolites in response to the increase in metal concentration [44]. Moreover, lichen communities growing in metal-rich ultramafic alpine areas may exhibit differences in terms of secondary metabolite production compared to those of adjacent non-ultramafic areas (e.g., lower frequency of species with depsidones) [45]. However, in other cases, lichen acids play no role in protection of thalli against airborne heavy metal pollutants [46] or against metals taken from a substrate [47]. Factors other than secondary metabolites may also affect metal accumulation as shown by two closely-related species containing the same lichen acid and growing in the same habitat but having dramatically different heavy metal concentrations [32].

The aim of the paper is to evaluate if lichen species producing different secondary compounds have distinct affinities to various rock types and their elemental constituents as well as to correlate the abundance of species containing different lichen metabolites with environmental parameters of the habitat. Towards this goal, we quantified lichen diversity and the related abundance of secondary 
metabolites, on six different rock types - chemically ranging from acid to ultrabasic lithologies through wide regions of Ural Mountains (Russia). In particular, the variability of secondary metabolites with respect to rock chemistry was compared in crustose lichens with respect to foliose-fruticose ones, to determine if the different levels of contact with the substrate may yield different patterns.

\section{Materials and Methods}

\subsection{Study Area}

Saxicolous lichens were studied in the Ural Mountains (Russia) in the territory of four administrative regions-Sverdlovsk, Chelyabinsk, Orenburg oblasts and the Republic of Bashkortostan (Figure 1). The territory belongs to the Middle and South Urals and stretches from the taiga subzone to grass steppes. Lithologically, it is a diverse area with outcrops of carbonate, ultrabasic, basic and acidic rocks. Most of the territory is strongly elevated and, apart from the zonal vegetation, is covered by mountain biomes represented by the Middle Ural taiga, which gradually changes to nemoral coniferous-deciduous and deciduous forests in the South Urals. Localities on the highest elevations visited during this study are covered by birch-larch woodlands and dark coniferous forests. The climate of the territory is moderately continental, with a cold winter and a warm summer. Average annual temperature varies from $-0.7^{\circ} \mathrm{C}$ to $+4.7^{\circ} \mathrm{C}[48]$.

\subsection{Field Survey}

Eighteen sampling localities were selected so as to reflect a spectrum of rock types and microclimates of the study area (Table 1). The localities were selected using a geological map of the Ural Mountains. As the territory of the Middle Urals is primarily covered by zonal forests, an attempt was made to find rock outcrops in elevated localities or on riverbanks. The rock outcrops are not equally distributed in the study area and, accordingly, seven localities were selected on serpentinites, four on limestones, three both on basalts and granites and one on quartzite. In every sampling locality, a series of $1 \times$ $1 \mathrm{~m}$ quadrats was established for which geographical coordinates and elevation were recorded. In every locality, the quadrats were applied to surfaces with different inclination and, where possible, with different azimuth. The number of quadrats selected was greater than or equal to ten per locality (except for locality 14). We followed the approach of preferential sampling [49], describing the most species-rich lichen assemblages and avoiding areas devoid of lichens. Ten records of lichen cover were made within every $1 \times 1 \mathrm{~m}$ quadrat using $10 \times 10 \mathrm{~cm}$ plots (Figure 2), leading to 80 to 200 records per locality. To facilitate counting, every plot was photographed with a superposed mesh, subdivided into $1001 \times 1 \mathrm{~cm}$ squares. The plots were distributed at corners, sides and in the center of every quadrat. The total number of plot records used in this study is 2480 . Specimens of lichens were collected together with rock samples for determination of species, their secondary chemistry and elemental composition of the rock substrates. In order to compare the diversity of secondary metabolites of lichens on different rock types we assembled a complete list of saxicolous species of the region, including those not represented in the descriptions, using published species lists [50-52]. Lichen nomenclature follows $[53,54]$.

For each sampling locality, the following parameters were evaluated: rock type and chemical composition (analytical procedure subsequently described), annual mean temperature, maximum temperature of the warmest month, minimum temperature of the coldest month, and the annual precipitation and heat index $[55,56]$, calculated using the formula cos (aspect $\left.-202.5^{\circ}\right) \times \operatorname{tg}$ (slope). The data on temperature and precipitation, namely average annual temperature, maximum temperature of the warmest month (July), minimum temperature of the coldest month (January) and annual precipitation, were extracted from the DIVA-GIS 7.5 application [57]. 


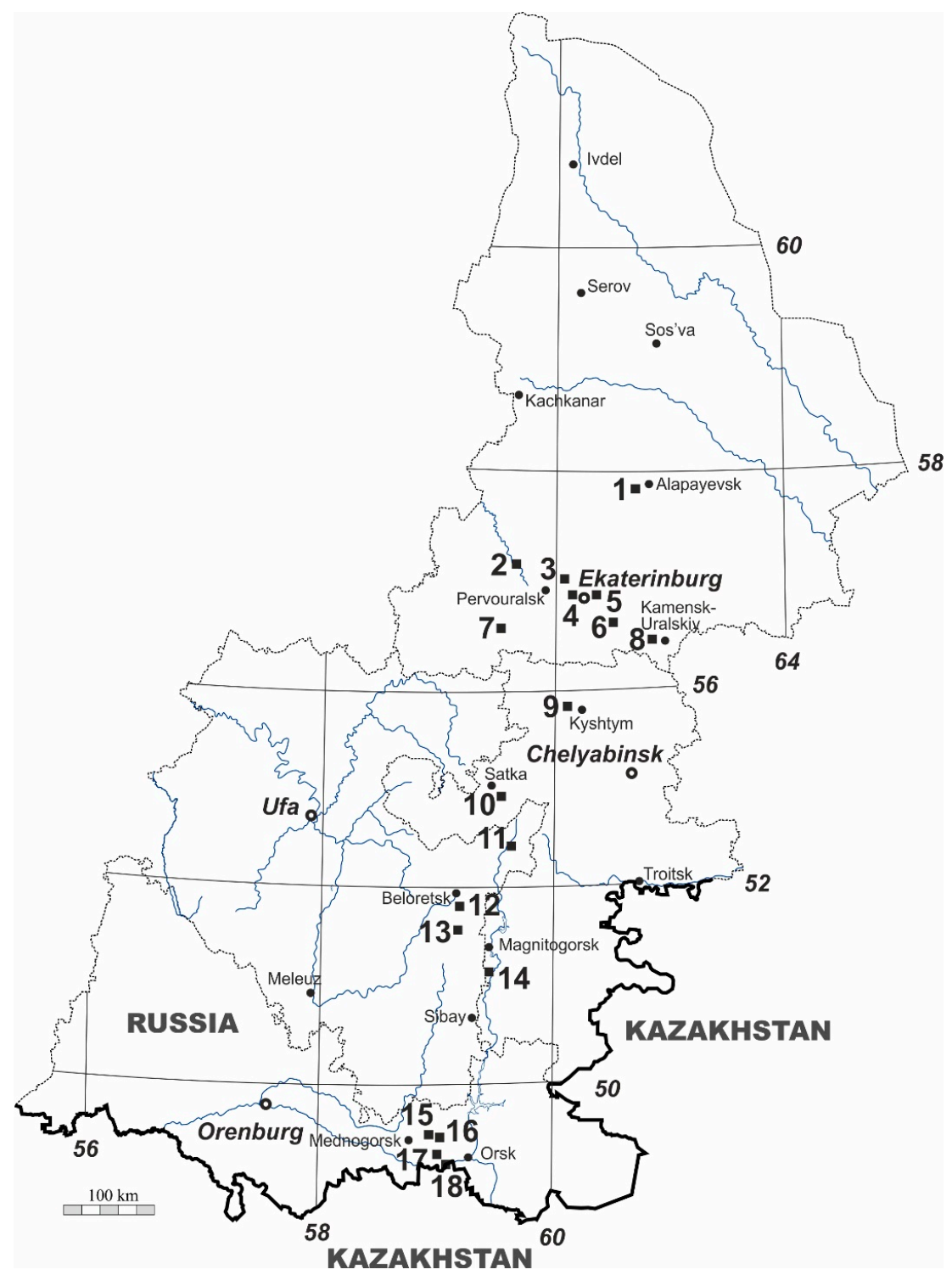

Figure 1. Study area and sampling localities. Modified from maps at d-maps.com.

Table 1. Coordinates, elevation and rock types in the study localities.

\begin{tabular}{|c|c|c|c|c|c|c|c|c|}
\hline $\mathbf{N}$ & Region & Locality & $\begin{array}{l}\text { Latitude, } \\
\quad \mathbf{N}\end{array}$ & $\begin{array}{l}\text { Longitude, } \\
\text { E }\end{array}$ & $\begin{array}{l}\text { Elevation, } \\
\mathrm{m}\end{array}$ & $\begin{array}{l}\text { Rock } \\
\text { Type }\end{array}$ & $\begin{array}{c}\text { Number of } \\
1 \times 1 \mathrm{~m} \\
\text { Quadrats }\end{array}$ & $\begin{array}{c}\text { Number of } \\
10 \times 10 \mathrm{~cm} \\
\text { Squares }\end{array}$ \\
\hline 1 & Sverdlovsk & Melkozyorovo village & $57^{\circ} 44^{\prime}$ & $61^{\circ} 28^{\prime}$ & 125 & Serpentinite & 10 & 100 \\
\hline 2 & Sverdlovsk & Kourovka settlement & $57^{\circ} 02^{\prime}$ & $59^{\circ} 38^{\prime}$ & 280 & Limestone & 15 & 150 \\
\hline 3 & Sverdlovsk & Petra Gronskogo rocks & $56^{\circ} 58^{\prime}$ & $60^{\circ} 18^{\prime}$ & 320 & Granite & 20 & 200 \\
\hline 4 & Sverdlovsk & Ekaterinburg, Baran peninsula & $56^{\circ} 50^{\prime}$ & $60^{\circ} 30^{\prime}$ & 280 & Granite & 20 & 200 \\
\hline 5 & Sverdlovsk & Ekaterinburg, Kamennye palatki & $56^{\circ} 50^{\prime}$ & $60^{\circ} 40^{\prime}$ & 280 & Granite & 10 & 100 \\
\hline 6 & Sverdlovsk & Dvurechensk settlement & $56^{\circ} 35^{\prime}$ & $61^{\circ} 03^{\prime}$ & 205 & Serpentinite & 18 & 180 \\
\hline 7 & Sverdlovsk & $\begin{array}{c}\text { Bazhukovo settlement } \\
\text { ‘Olenyi Ruchyi' National park }\end{array}$ & $56^{\circ} 30^{\prime}$ & $59^{\circ} 15^{\prime}$ & 300 & Limestone & 20 & 200 \\
\hline 8 & Sverdlovsk & Kodinka village & $56^{\circ} 25^{\prime}$ & $61^{\circ} 48^{\prime}$ & 120 & Limestone & 16 & 160 \\
\hline 9 & Chelyabinsk & Egoza mountain & $55^{\circ} 45^{\prime}$ & $60^{\circ} 26^{\prime}$ & 570 & Serpentinite & 10 & 100 \\
\hline 10 & Chelyabinsk & Zyuratkul' mountain & $54^{\circ} 57^{\prime}$ & $59^{\circ} 10^{\prime}$ & 1170 & Quartzite & 20 & 200 \\
\hline 11 & Bashkortostan & Kalkanovo village & $54^{\circ} 25^{\prime}$ & $59^{\circ} 20^{\prime}$ & 670 & Serpentinite & 12 & 120 \\
\hline 12 & Bashkortostan & Shigayevo village & $53^{\circ} 48^{\prime}$ & $58^{\circ} 11^{\prime}$ & 560 & Serpentinite & 12 & 120 \\
\hline 13 & Bashkortostan & Kushai mountain & $53^{\circ} 43^{\prime}$ & $58^{\circ} 37^{\prime}$ & $507-920$ & Basalt & 15 & 150 \\
\hline 14 & Chelyabinsk & Yangelskiy settlement & $53^{\circ} 13^{\prime}$ & $58^{\circ} 54^{\prime}$ & 350 & Limestone & 8 & 80 \\
\hline 15 & Orenburg & Mazovo village & $51^{\circ} 30^{\prime}$ & $58^{\circ} 01^{\prime}$ & 340 & Serpentinite & 12 & 120 \\
\hline 16 & Orenburg & Gainulino village & $51^{\circ} 23^{\prime}$ & $58^{\circ} 18^{\prime}$ & 270 & Basalt & 10 & 100 \\
\hline 17 & Orenburg & Akkermanovka settlement & $51^{\circ} 08^{\prime}$ & $58^{\circ} 02^{\prime}$ & 300 & Serpentinite & 10 & 100 \\
\hline 18 & Orenburg & Khabarnoye settlement & $51^{\circ} 06^{\prime}$ & $58^{\circ} 06^{\prime}$ & 220 & Basalt & 10 & 100 \\
\hline
\end{tabular}




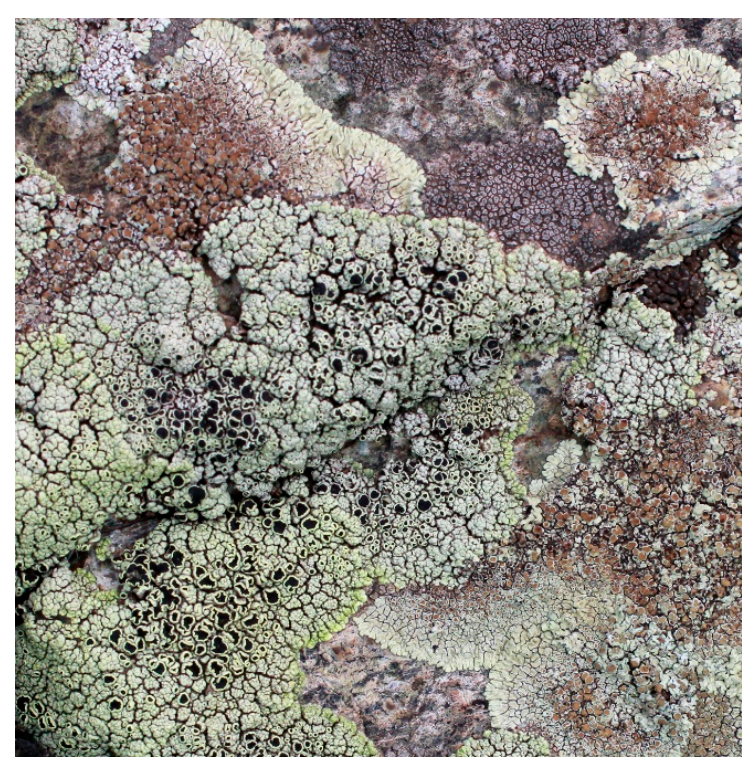

(a)

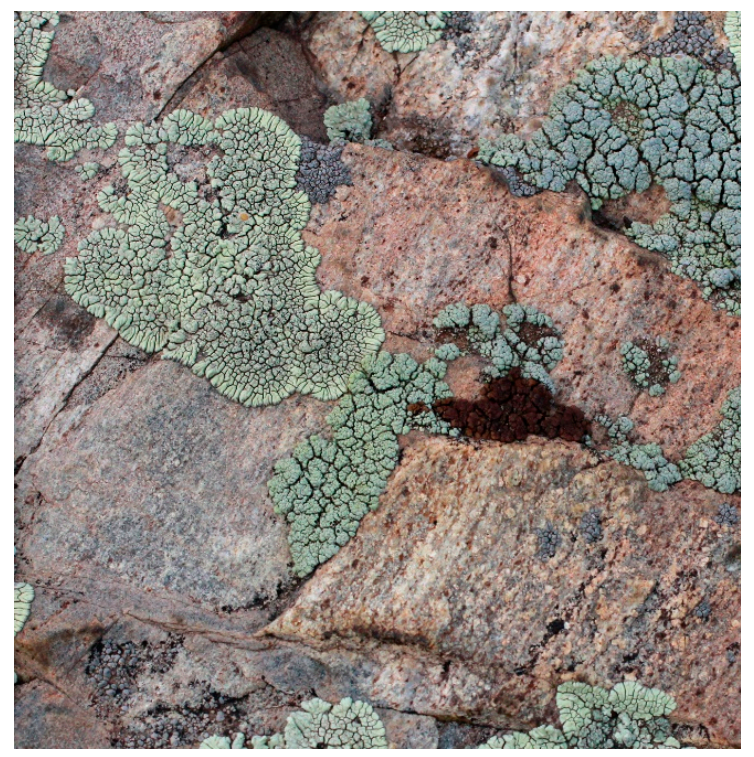

(c)

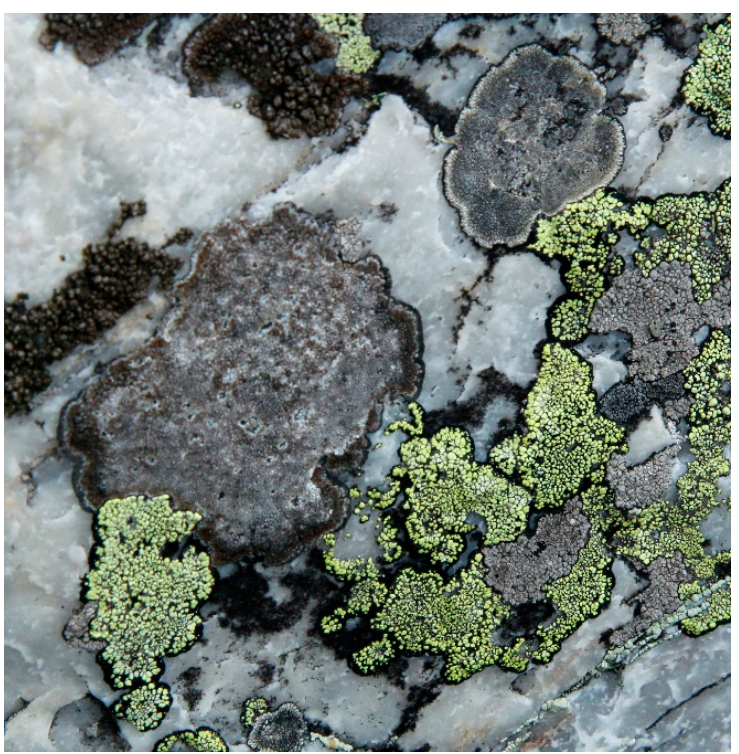

(b)

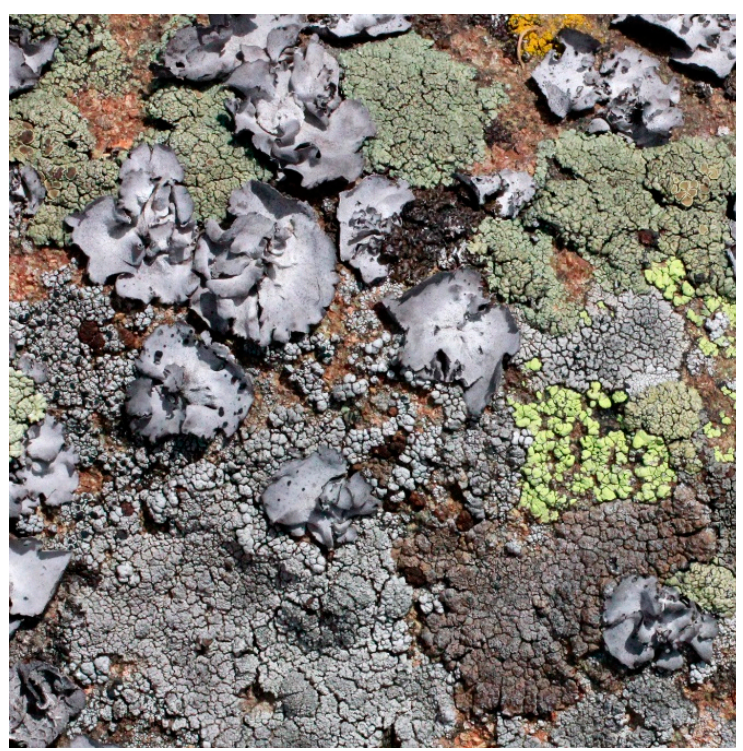

(d)

Figure 2. Lichen groupings on three rock types. (a) Serpentinite, Akkermanovka settlement, locality 17 (Lecanora argopholis (Ach.) Ach., Protoparmeliopsis muralis (Schreb.) M.Choisy and Circinaria spp.); (b) Quartzite, Zyuratkul' range, locality 10 (Rhizocarpon geographicum (L.) DC., Sporastatia testudinea (Ach.) A. Massal. and Protoparmelia badia (Hoffm.) Hafellner); (c) Basalt, Khabarnoye settlement, locality 18 (Dimelaena oreina (Ach.) Norman and Lecanora argopholis); (d) Basalt, Kushai mountain, locality 13 (Umbilicaria subglabra (Nyl.) Harm., Immersaria athroocarpa (Ach.) Rambold \& Pietschm., Aspicilia cinerea (L.) Körb., Lecanora spp.). Bar $=1 \mathrm{~cm}$.

\subsection{Analytical Procedures}

Secondary products were analyzed by applying standard thin-layer chromatography techniques [58,59] in solvent systems A (toluene: 1,4-dioxane:acetic acid, 180:45:5), B (hexane:diethyl ether:formic acid, 140:72:18) and C (toluene:acetic acid, 170:30).

For the determination of elemental composition of rocks, five rock samples from each sampling locality were ground in a porcelain mortar, oven-dried at $70^{\circ} \mathrm{C}$ for $48 \mathrm{~h}$, and $200 \mathrm{mg}$ of each sample was 
weighed and placed in fluoroplastic glasses with $1 \mathrm{~mL}$ of $\mathrm{HF}, 5 \mathrm{~mL}$ of $\mathrm{HNO}_{3}, 2 \mathrm{~mL}$ of $\mathrm{HCl}$ and $2 \mathrm{~mL}$ of deionized water, followed by digestion in a MARS 5 microwave oven (CEM Corporation, Matthews, NC, USA). After cooling, $7 \mathrm{~mL}$ of $4 \%$ boric acid were added and the solutions were transferred into $25-\mathrm{mL}$ volumetric flasks and topped up to volume by deionized water. Concentrations of $\mathrm{Ba}, \mathrm{Ca}, \mathrm{Co}, \mathrm{Cr}$, $\mathrm{Cu}, \mathrm{Fe}, \mathrm{Mg}, \mathrm{Mn}, \mathrm{Ni}, \mathrm{Sr}$ and $\mathrm{Zn}$ in rock samples were determined by inductively coupled plasma-atomic emission spectroscopy (iCAP 6500 Duo, Thermo Fischer Scientific, Waltham, MA, USA).

For determination of $\mathrm{pH}$ and conductivity of water extraction, $2 \mathrm{~g}$ of powdered rock samples were poured into $20 \mathrm{~mL}$ of distilled water and left for $48 \mathrm{~h}$ with periodical shaking. The $\mathrm{pH}$ was measured after precipitation of particles with a $\mathrm{pH}$ meter (Anion 4100, Novosibirsk, Russia) and conductivity was determined using HI 98129 Combo meter (Hanna Instruments, Port Louis, Mauritius).

\subsection{Statistical Analyses}

Matrices of (a) metabolite occurrence with respect to lichen species, (b) metal contents, $\mathrm{pH}$ and conductivity for the different rock types, (c) cover of species with different metabolites on every $10 \times 10$ $\mathrm{cm}$ plot, (d) geographical and environmental parameters for every locality were assembled as Microsoft Excel electronic tables. Total number of species on every rock type, average number of species within 10 $\times 10 \mathrm{~cm}$ plots, number of secondary metabolites and metabolite to species ratio (number of secondary metabolites/number of species) were calculated using Microsoft Excel. Shannon Diversity Index for every rock type and Chi-Square values were calculated in the PAST 3.18 package [60]. The metal content in the substrate, the $\mathrm{pH}$ and the conductivity in relation to the localities were analyzed as raw data using Principal Component Analysis (PCA). The relationships of cover of species to environmental variables and characteristics of substrates were analyzed using Canonical Correspondence Analysis (CCA) in CANOCO 5.0 [61].

To avoid the influence of species-specific patterns in the distribution of lichens, depending on the parameters of microhabitats, the cover of species containing the same lichen metabolite was summed in every description within $10 \times 10 \mathrm{~cm}$ plot. If a species contained several lichen metabolites, its cover was counted correspondingly several times for every lichen acid in a thallus. CCA analyses were separately performed for crustose and foliose-fruticose species for comparison.

\section{Results}

\subsection{Species and Secondary Metabolite Diversity}

Five hundred and forty three lichen species ( 347 crustose, 141 foliose and 55 fruticose) were found inhabiting rock substrates in the Middle and South Urals. One hundred and ninety six (i.e., $36 \%$ of total species) contained no secondary metabolites. Twenty seven lichen metabolites were found in only one species and fourteen metabolites were present in 10 or more species. The most common amongst them was atranorin, which was found in 73 species (Table 2). Distribution of lichen acids within the morphological groups was unequal. The most chemically diverse were fruticose lichens which contained 24 metabolites in 55 species (ratio 0.44 ), while foliose lichens displayed 43 metabolites in 141 taxa (ratio 0.30), and 347 crustose species contained only 57 lichen acids (ratio 0.16).

Only atranorin was distributed in lichens independent of their life form (Table 2); it was a component of a wide range of crustose, foliose and fruticose species (taxonomically attributable to 10 families: Baeomycetaceae, Cladoniaceae, Graphidaceae, Icmadophilaceae, Lecanoraceae, Parmeliaceae, Physciaceae, Ramalinaceae, Stereocaulaceae and Tephromelataceae). The presence of certain metabolites was often correlated with a certain growth form. Gyrophoric acid and zeorin were found in crustose and foliose species; usnic acid had a higher affinity to fruticose and foliose taxa (mostly Cladoniaceae, Parmeliaceae, Ramalinaceae). Fumarprotocetraric acid was also common in the dimorphic-fruticose Cladoniaceae. Norstictic, stictic, xanthones and anthraquinones were mainly found in crustose species. In particular, anthraquinones were specific to nearly all Teloschistaceae but only 3 out of 41 saxicolous species of this family were foliose. Other metabolites, which did not display a strong dependence on 
life form, were characteristic of certain genera or families: lobaric acid was a secondary metabolite of Protoparmelia spp. (crustose) and Stereocaulaceae (fruticose), psoromic acid was found mainly in Rhizocarpon spp. (crustose) and Rhizoplaca spp. (foliose).

Table 2. Major secondary metabolites of saxicolous lichens of different morphological groups.

\begin{tabular}{ccccc}
\hline \multirow{2}{*}{ Secondary Metabolite } & \multicolumn{4}{c}{ Number of Species Containing the Metabolite } \\
\cline { 2 - 5 } & All Species & Crustose Species & Foliose Species & Fruticose Species \\
\hline Atranorin & 73 & 36 & 20 & 17 \\
Usnic acid & 42 & 10 & 14 & 18 \\
Gyrophoric acid & 41 & 19 & 22 & 0 \\
Zeorin & 37 & 19 & 15 & 3 \\
Norstictic acid & 36 & 30 & 4 & 2 \\
Anthraquinones & 35 & 32 & 3 & 0 \\
Stictic acid & 32 & 27 & 4 & 17 \\
Fumarprotocetraric acid & 21 & 1 & 3 & 0 \\
Lecanoric acid & 14 & 6 & 8 & 6 \\
Lobaric acid & 11 & 7 & 1 & 0 \\
Psoromic acid & 10 & 10 & 0 & 0 \\
Xanthones & 10 & & & \\
\hline
\end{tabular}

Species and secondary metabolite quantities were unequal on different rock types. The most species-rich substrate was limestone (233 species) followed by quartzite, basalt and serpentinite (Table 3). The total diversity of lichen biota on a particular rock substrate did not correlate with species richness within $10 \times 10 \mathrm{~cm}$ plots. Despite their high biodiversity, limestones have on average as low as 3 species within a single description. High diversity of species on limestone may depend on the diversity of microhabitats in which this rock was found. Lichen flora of quartzite and basalt was enriched by the presence of alpine and tundra species at the highest elevations. The number of secondary metabolites in lichens on different rocks, however, did not correlate with their species diversity. For example, the greatest diversity of secondary metabolites was found on basalt and the lowest on limestone. Metabolite to species ratio was highest on granite and pyroxenite and this ratio was the same for all life forms of lichens. Average number of metabolites per species decreases gradually from quartzites to limestone.

Table 3. Species and secondary metabolite diversity on different rock types.

\begin{tabular}{|c|c|c|c|c|c|c|}
\hline Measured Feature & Quartzite & Granite & Basalt & Pyroxenite & Serpentinite & Limestone \\
\hline Total number of species & 198 & 93 & 193 & 107 & 167 & 233 \\
\hline Number of species within $10 \times 10 \mathrm{~cm}$ plots & $3.19 \pm 0.24$ & $2.31 \pm 0.14$ & $4.41 \pm 0.16$ & $\mathrm{n} / \mathrm{a}$ & $3.88 \pm 0.18$ & $2.81 \pm 0.11$ \\
\hline Shannon $\mathrm{H}$ diversity index & $0.75 \pm 0.07$ & $0.45 \pm 0.04$ & $1.01 \pm 0.03$ & $\mathrm{n} / \mathrm{a}$ & $0.81 \pm 0.04$ & $0.71 \pm 0.03$ \\
\hline Metabolite to species ratio & 0.32 & 0.54 & 0.35 & 0.46 & 0.30 & 0.18 \\
\hline Average number of metabolites in one species & $1.72 \pm 0.09^{\mathrm{A}}$ & $1.56 \pm 0.11^{\mathrm{B}}$ & $1.44 \pm 0.08^{\mathrm{B}}$ & $1.61 \pm 0.11^{\mathrm{A}, \mathrm{B}}$ & $1.14 \pm 0.09^{\mathrm{C}}$ & $0.74 \pm 0.07^{\mathrm{D}}$ \\
\hline
\end{tabular}

Values in the last row marked by the same letter are statistically insignificant at $p=0.05$.

The proportion of crustose species without lichen acids was five times higher on limestone compared to that on quartzite (Figure 3a). The only metabolite that increased its percentage in species on alkaline substrata was anthraquinone (parietin). Gyrophoric, stictic and usnic acids were more common in lichens on acidic substrata but these differences were statistically insignificant for the latter. No particular trend was seen for norstictic acid, atranorin and zeorin; however, the latter two substances were found in substantially lower percentages on limestone. The differences in proportions of secondary metabolites were statistically insignificant for crustose lichens growing on quartzite, granite and basalt (Chi-square $=9.4, p=0.9)$ and significant for species growing on pyroxenite, serpentinite and limestone $(p=0.0001)$. 


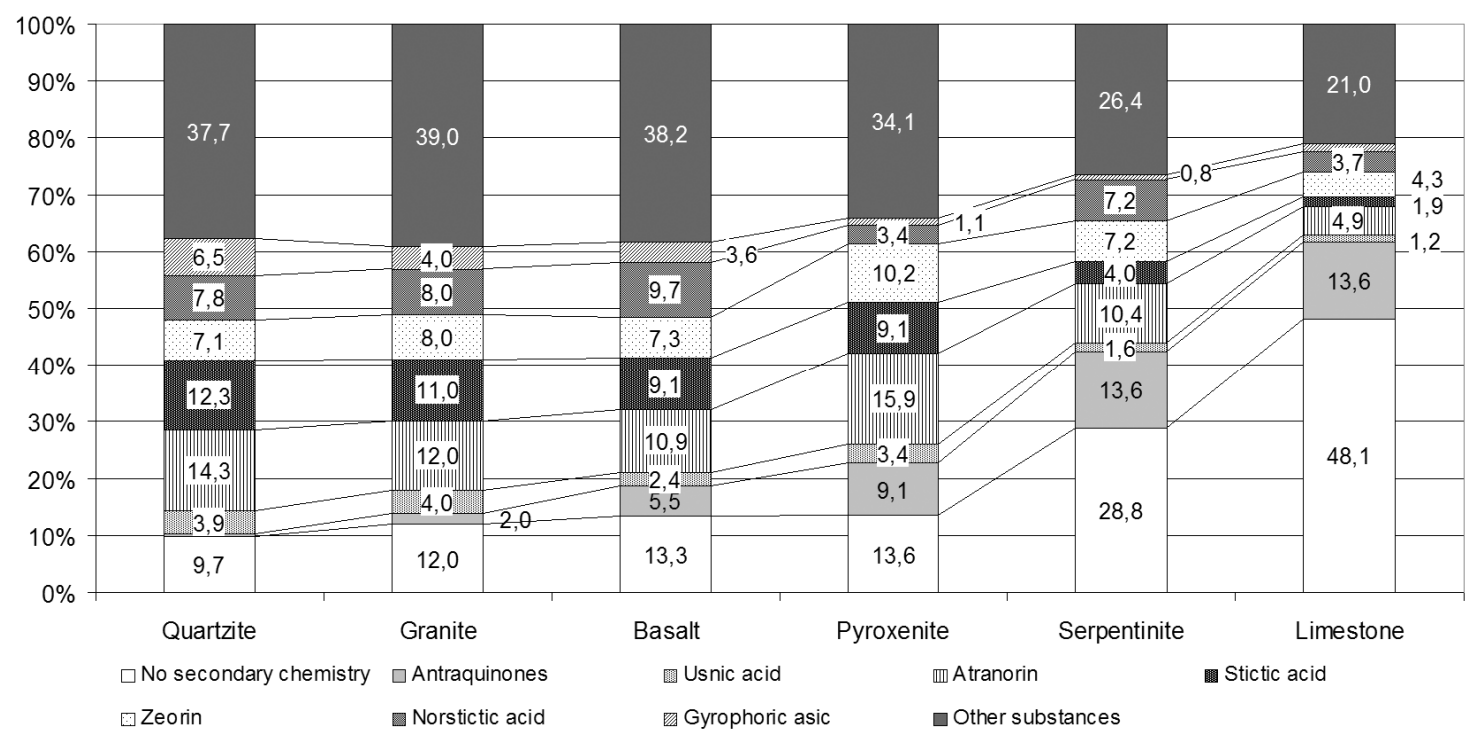

(a)

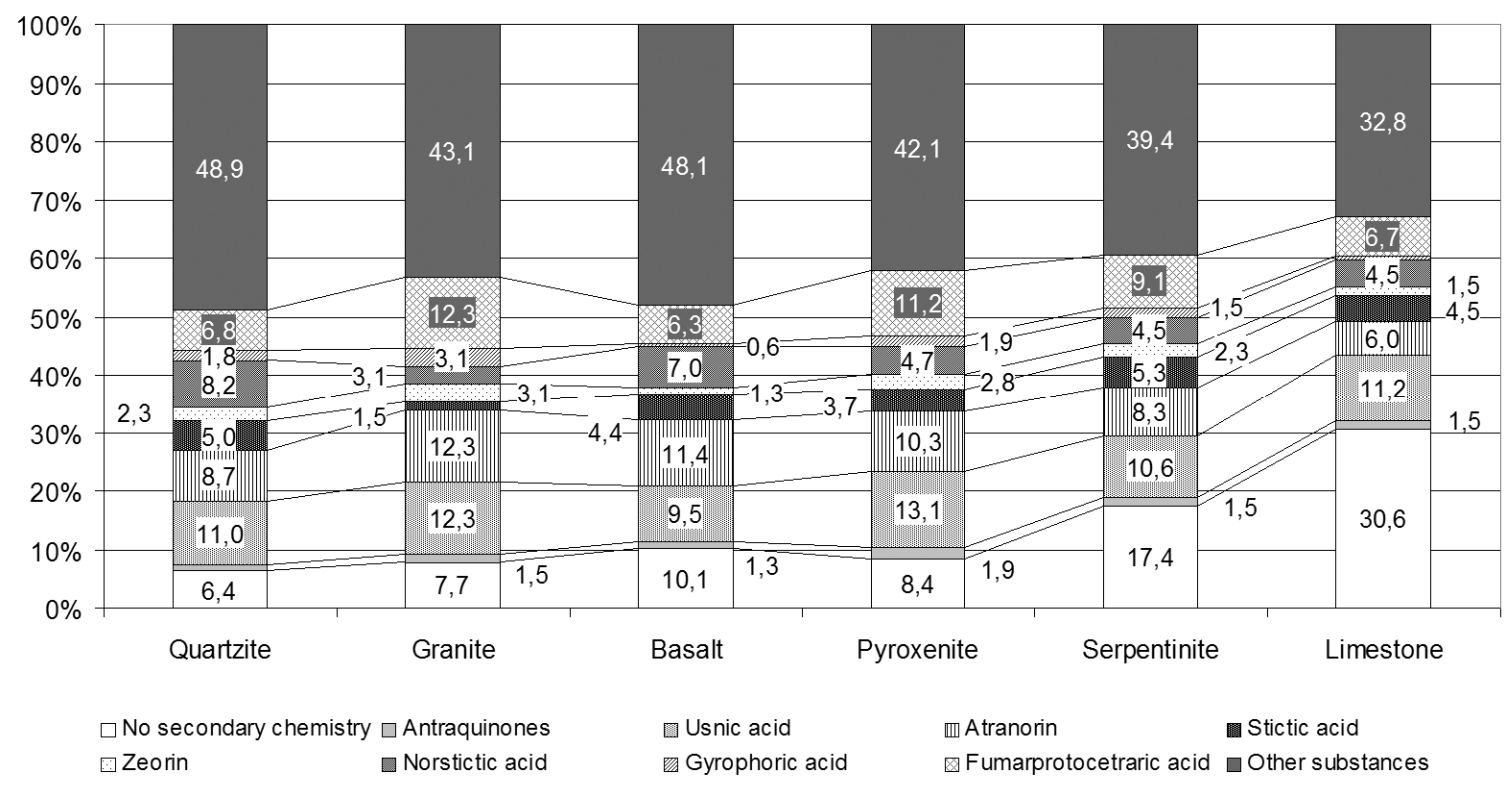

(b)

Figure 3. Percentage of lichen species containing eight major secondary metabolites on different rock types. (a) crustose species, (b) foliose and fruticose species.

Within foliose and fruticose species there was a lower proportion of species with no secondary metabolites on every rock type but, like in crustose lichens, the percentage of species without metabolites on limestone was fivefold compared to that on quartzite (Figure $3 b$ ). Other major secondary metabolites did not appear to be dependent on a rock type. The differences in proportions of secondary metabolites were significant for foliose and fruticose lichens growing on quartzite and limestone only (Chi-square $=33.7, p=0.0003)$.

\subsection{Chemical Properties of Rock Substrates}

Rock substrates strongly varied in metal content as well as $\mathrm{pH}$ and conductivity $\left(\mathrm{S}^{*} 10^{-3} / \mathrm{m}\right)$ of water extracts. The highest $\mathrm{pH}$ was found in limestone and serpentinite (with averages in the range 7.18-8.18) (Table 4). 
Table 4. Chemistry of rocks in the studied localities.

\begin{tabular}{|c|c|c|c|c|c|c|c|c|c|c|c|c|c|}
\hline \multirow{2}{*}{ Rock/Locality } & \multirow{2}{*}{$\mathrm{pH}$} & \multirow{2}{*}{$\begin{array}{l}\text { Conductivity, } \\
\mathrm{S}^{*} 10^{-3} / \mathrm{m}\end{array}$} & \multicolumn{11}{|c|}{ Metals, $\mu \mathrm{g} / \mathrm{g}$ (Average \pm Standard Error) } \\
\hline & & & Ва & $\mathrm{Ca}$ & Co & $\mathrm{Cr}$ & $\mathrm{Cu}$ & $\mathrm{Fe}$ & $\mathrm{Mg}$ & Mn & $\mathrm{Ni}$ & $\mathrm{Sr}$ & Zn \\
\hline S1 & $7.36 \pm 0.01$ & $341 \pm 31$ & $5 \pm 2$ & $928 \pm 151$ & $68 \pm 1$ & $438 \pm 19$ & $30 \pm 15$ & $29,491 \pm 14,966$ & $124,271 \pm 62,183$ & $571 \pm 4$ & $1677 \pm 290$ & $2 \pm 0.0$ & $35 \pm 6$ \\
\hline S6 & $8.20 \pm 0.06$ & $294 \pm 12$ & $40 \pm 25$ & $9410 \pm 5633$ & $32 \pm 6$ & $770 \pm 535$ & $77 \pm 34$ & $25,835 \pm 4813$ & $58,592 \pm 18,636$ & $446 \pm 92$ & $526 \pm 241$ & $7 \pm 2$ & $31 \pm 8$ \\
\hline S9 & $7.88 \pm 0.02$ & $205 \pm 1$ & $6 \pm 2$ & $7544 \pm 746$ & $16 \pm 6$ & $413 \pm 74$ & $8 \pm 2$ & $13,266 \pm 2818$ & $43,449 \pm 8601$ & $219 \pm 28$ & $569 \pm 143$ & $1 \pm 0.0$ & $24 \pm 3$ \\
\hline S 11 & $8.18 \pm 0.04$ & $342 \pm 43$ & $8 \pm 3$ & $376 \pm 62$ & $79 \pm 8$ & $256 \pm 31$ & $5 \pm 0.0$ & $39,370 \pm 530$ & $183,899 \pm 6422$ & $585 \pm 35$ & $1550 \pm 76$ & $2 \pm 0.0$ & $40 \pm 3$ \\
\hline S 12 & $8.08 \pm 0.02$ & $239 \pm 9$ & $5 \pm 0.0$ & $613 \pm 23$ & $70 \pm 5$ & $576 \pm 126$ & $3 \pm 0.0$ & $41,284 \pm 1964$ & $181,878 \pm 13,159$ & $567 \pm 18$ & $1553 \pm 95$ & $1 \pm 0.0$ & $17 \pm 0.0$ \\
\hline S 15 & $8.18 \pm 0.08$ & $289 \pm 12$ & $9 \pm 3$ & $529 \pm 89$ & $71 \pm 7$ & $281 \pm 52$ & $4 \pm 2$ & $39,499 \pm 1707$ & $200,647 \pm 11,743$ & $482 \pm 49$ & $1768 \pm 309$ & $3 \pm 1$ & $17 \pm 2$ \\
\hline S 17 & $8.08 \pm 0.08$ & $324 \pm 21$ & $7 \pm 3$ & $42,726 \pm 28,779$ & $61 \pm 14$ & $184 \pm 26$ & $3 \pm 1$ & $37,779 \pm 5306$ & $166,937 \pm 7170$ & $534 \pm 135$ & $1564 \pm 438$ & $23 \pm 10$ & $16 \pm 3$ \\
\hline L 2 & $7.86 \pm 0.02$ & $318 \pm 43$ & $11 \pm 3$ & $305,943 \pm 10,157$ & nd & $1 \pm 1$ & $12 \pm 1$ & $290 \pm 169$ & $2223 \pm 167$ & $48 \pm 18$ & $2 \pm 2$ & $194 \pm 46$ & $9 \pm 4$ \\
\hline L 7 & $8.00 \pm 0.01$ & $247 \pm 44$ & $3 \pm 2$ & $375,458 \pm 6176$ & nd & nd & $8 \pm 0.0$ & $74 \pm 13$ & $1716 \pm 164$ & $28 \pm 10$ & $1 \pm 0.0$ & $128 \pm 9$ & $2 \pm 0.0$ \\
\hline L 8 & $7.18 \pm 0.04$ & $278 \pm 29$ & $10 \pm 3$ & $323,865 \pm 7008$ & nd & $7 \pm 1$ & $10 \pm 0.0$ & $347 \pm 28$ & $13,112 \pm 5037$ & $52 \pm 18$ & $4 \pm 2$ & $136 \pm 12$ & $5 \pm 1$ \\
\hline L 14 & $7.88 \pm 0.18$ & $298 \pm 52$ & $8 \pm 2$ & $384,928 \pm 17,198$ & nd & $7 \pm 2$ & $7 \pm 0.0$ & $128 \pm 54$ & $4263 \pm 855$ & $61 \pm 14$ & nd & $118 \pm 38$ & $6 \pm 1$ \\
\hline G 3 & $6.48 \pm 0.21$ & $47 \pm 6$ & $65 \pm 34$ & $1076 \pm 452$ & $4 \pm 1$ & $9 \pm 3$ & $14 \pm 4$ & $7289 \pm 2170$ & $5090 \pm 1884$ & $186 \pm 13$ & $32 \pm 23$ & $12 \pm 7$ & $41 \pm 8$ \\
\hline G 4 & $6.68 \pm 0.15$ & $35 \pm 9$ & $38 \pm 4$ & $640 \pm 157$ & nd & $2 \pm 0.0$ & $9 \pm 2$ & $5277 \pm 719$ & $1688 \pm 491$ & $223 \pm 49$ & $2 \pm 0.0$ & $5 \pm 2$ & $44 \pm 6$ \\
\hline G 5 & $6.64 \pm 0.08$ & $206 \pm 24$ & $257 \pm 89$ & $1558 \pm 55$ & nd & $6 \pm 1$ & $16 \pm 2$ & $7620 \pm 1225$ & $3555 \pm 554$ & $199 \pm 30$ & $6 \pm 0.0$ & $10 \pm 1$ & $36 \pm 5$ \\
\hline В 13 & $7.74 \pm 0.04$ & $206 \pm 38$ & $47 \pm 13$ & $34,996 \pm 7749$ & $22 \pm 1$ & $33 \pm 5$ & $57 \pm 4$ & $46,306 \pm 372$ & $26,663 \pm 2538$ & $767 \pm 55$ & $33 \pm 8$ & $32 \pm 7$ & $58 \pm 3$ \\
\hline В 16 & $7.82 \pm 0.03$ & $352 \pm 41$ & $19 \pm 2$ & $7881 \pm 414$ & $14 \pm 2$ & $23 \pm 8$ & $8 \pm 3$ & $15,687 \pm 2573$ & $19,252 \pm 3465$ & $228 \pm 31$ & $95 \pm 37$ & $7 \pm 0.0$ & $22 \pm 4$ \\
\hline B 18 & $7.35 \pm 0.15$ & $87 \pm 19$ & $171 \pm 48$ & $3387 \pm 924$ & $2 \pm 0.0$ & $9 \pm 8$ & $13 \pm 4$ & $24,667 \pm 1895$ & $6920 \pm 471$ & $480 \pm 124$ & $6 \pm 3$ & $15 \pm 9$ & $36 \pm 9$ \\
\hline Q 10 & $6.16 \pm 0.06$ & $39 \pm 9$ & $28 \pm 8$ & $183 \pm 19$ & nd & $1 \pm 0.0$ & $1 \pm 0.0$ & $244 \pm 93$ & $316 \pm 199$ & $6 \pm 1$ & $3 \pm 2$ & $2 \pm 0.0$ & $3 \pm 1$ \\
\hline
\end{tabular}

Numbers of localities follow Table 1. S—serpentinite, L-limestone, G—granite, B—basalt, Q—quartzite. Nd—not detected. 
The lowest concentrations of all studied elements were found in quartzite (Table 4). Calcium was a dominant element in limestone (up to 38.5\%). Magnesium had its highest concentrations in serpentinite (up to $20 \%$ ). Iron ( $\mathrm{Fe}$ ) was the third most common element in the examined rocks, which was most abundant in serpentinite and basalt (up to $4.6 \%$ ).

Two elements ( $\mathrm{Ba}$ and $\mathrm{Cu}$ ) did not show a statistically significant affinity to other metals in the rock types. A strong correlation was found between $\mathrm{Co}, \mathrm{Fe}, \mathrm{Mg}$ and $\mathrm{Ni}$, which were found together in serpentinites and between $\mathrm{Fe}$ and $\mathrm{Mn}$, which were common in serpentinite and basalt. $\mathrm{Ca}$ and $\mathrm{Sr}$ concentrations were correlated and found together in limestone. Conductivity was correlated with $\mathrm{pH}$, showing their highest values in limestone and serpentinite and associated with the concentration of the most abundant elements- $\mathrm{Ca}$ and $\mathrm{Mg}$ - in these rocks (Table 5).

Table 5. Pearson correlation coefficients between elemental concentrations in rocks, $\mathrm{pH}$ and conductivity of water extracts.

\begin{tabular}{|c|c|c|c|c|c|c|c|c|c|c|c|c|}
\hline $\begin{array}{l}\text { Edaphic } \\
\text { Feature }\end{array}$ & Conductivity & Ba & $\mathrm{Ca}$ & Co & $\mathrm{Cr}$ & $\mathrm{Cu}$ & $\mathrm{Fe}$ & $\mathrm{Mg}$ & Mn & $\mathrm{Ni}$ & $\mathrm{Sr}$ & $\mathrm{Zn}$ \\
\hline $\mathrm{pH}$ & 0.67 & -0.41 & 0.13 & 0.57 & 0.38 & 0.12 & 0.53 & 0.58 & 0.45 & 0.52 & 0.10 & -0.11 \\
\hline Conductivity & & -0.31 & 0.24 & 0.38 & 0.30 & 0.08 & 0.16 & 0.35 & 0.16 & 0.44 & 0.25 & -0.23 \\
\hline $\mathbf{B a}$ & & & -0.21 & -0.34 & -0.24 & 0.09 & -0.12 & -0.33 & -0.03 & -0.33 & -0.13 & 0.37 \\
\hline $\mathrm{Ca}$ & & & & -0.39 & -0.26 & -0.10 & -0.46 & -0.34 & -0.48 & -0.35 & 0.91 & -0.55 \\
\hline Co & & & & & 0.40 & -0.02 & 0.83 & 0.93 & 0.74 & 0.85 & -0.40 & 0.18 \\
\hline $\mathrm{Cr}$ & & & & & & 0.48 & 0.22 & 0.39 & 0.19 & 0.51 & -0.27 & -0.03 \\
\hline $\mathrm{Cu}$ & & & & & & & 0.18 & -0.11 & 0.24 & -0.13 & -0.06 & 0.42 \\
\hline $\mathrm{Fe}$ & & & & & & & & 0.81 & 0.90 & 0.58 & -0.43 & 0.45 \\
\hline Mg & & & & & & & & & 0.66 & 0.87 & -0.36 & 0.04 \\
\hline Mn & & & & & & & & & & 0.47 & -0.43 & 0.60 \\
\hline $\mathrm{Ni}$ & & & & & & & & & & & -0.36 & -0.05 \\
\hline $\mathrm{Sr}$ & & & & & & & & & & & & -0.42 \\
\hline
\end{tabular}

Values in bold are significant at $p<0.05$.

PCA (Figure 4), which ordinated sampling sites on the basis of the chemical contents of rocks, explained $94.7 \%$ of total variance and separated the different rock types. Localities with limestones represent a separate group with high $\mathrm{Ca}$ and $\mathrm{Sr}$. Sites with granites group with quartzite and one locality with 'basalt.' Habitats with serpentinized rocks are subdivided into groups with apoharzburgite serpentinites $(1,11,12,15)$ and apoharzburgite antigorite-talc-carbonate slates $(6,9,17)$. The rocks regarded as 'basalts' are chemically not uniform and appeared to be close to granites or serpentinized rocks in some locations.

\subsection{Secondary Metabolites and Chemistry of Rocks}

Canonical correspondence analysis (CCA) on relationships between metabolites and the chemical composition of rock types showed different results for crustose and foliose-fruticose species (Figure 5). In both CCAs, $\mathrm{Ca}, \mathrm{Sr}, \mathrm{Ba}$ and $\mathrm{Zn}$ in the substrate have high loading on the first axis (57.5\% of variance for foliose-fruticose and $48.9 \%$ for crustose) and the second axis (37.4\% and $27.4 \%$, for foliose-fruticose and crustose, respectively) reflects other metals $(\mathrm{Co}, \mathrm{Cr}, \mathrm{Cu}, \mathrm{Fe}, \mathrm{Mg}, \mathrm{Mn}, \mathrm{Ni})$ as well as $\mathrm{pH}$ and conductivity, however, the ordination of metabolites is different for crustose and foliose-fruticose species.

In the CCA, dealing with foliose-fruticose lichens, species with norstictic, stictic acids and zeorin were the most abundant on granites and were positively correlated with $\mathrm{Ba}$ and $\mathrm{Zn}$ content in the substrate and negatively correlated with $\mathrm{pH}$. Lichens containing gyrophoric, lecanoric and psoromic acids and melanins had an affinity to basalt and their cover correlated with the content of $\mathrm{Fe}, \mathrm{Mg}$ and $\mathrm{Mn}$ in the substrate and did not depend on $\mathrm{pH}$. Species with usnic acid are intermediate between these two groups and equally common on granite and basalt. Foliose and fruticose lichens with anthraquinones, atranorin, fumarprotocetraric acid or lacking secondary metabolites were distributed equally on limestone and serpentinite in habitats with high $\mathrm{Ca}, \mathrm{pH}$ and conductivity (Figure 5a). 


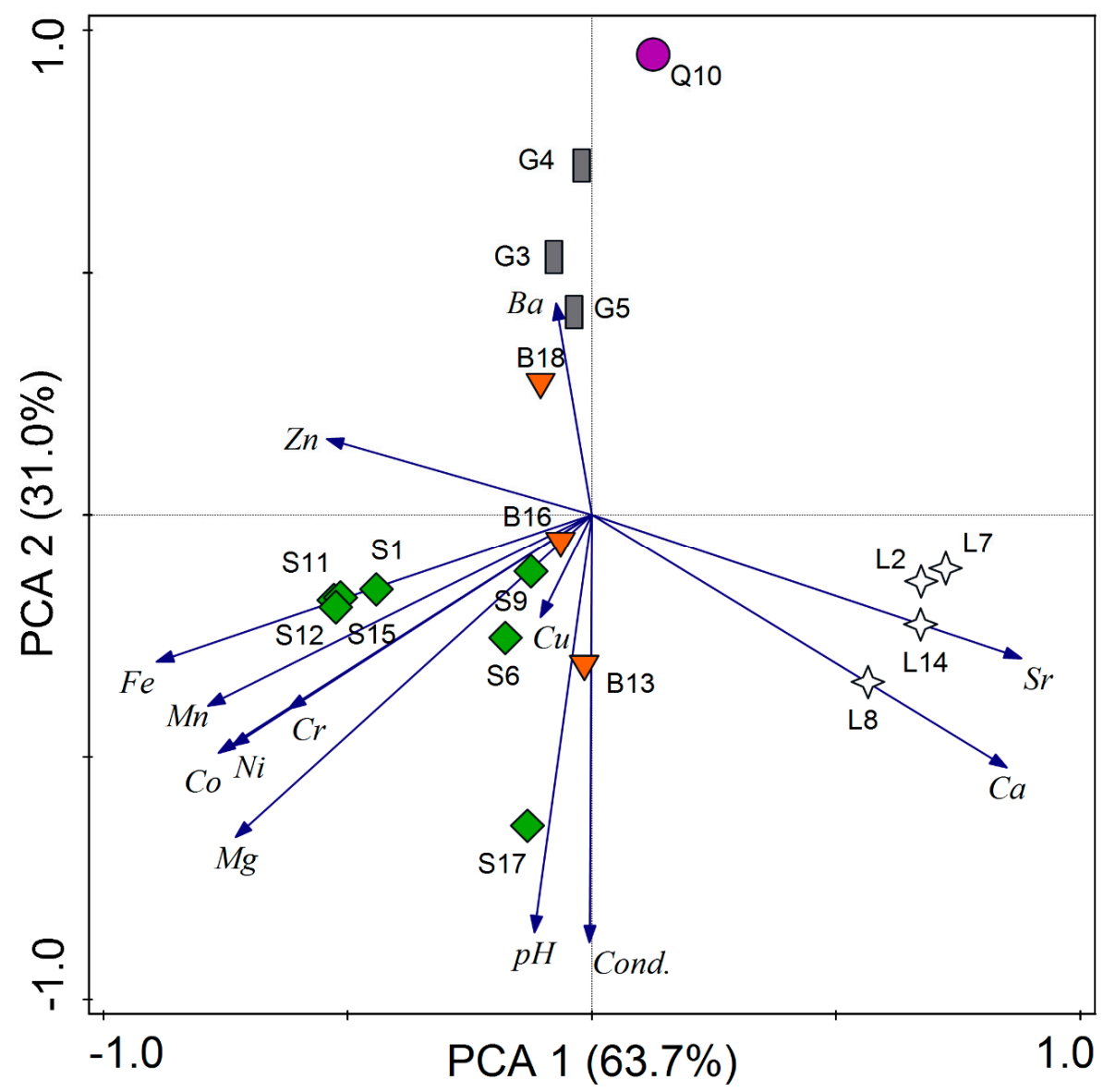

Figure 4. Ordination of the rock types from the different sampling localities $(n=18)$ on the basis of $\mathrm{pH}$, conductivity and metal content.

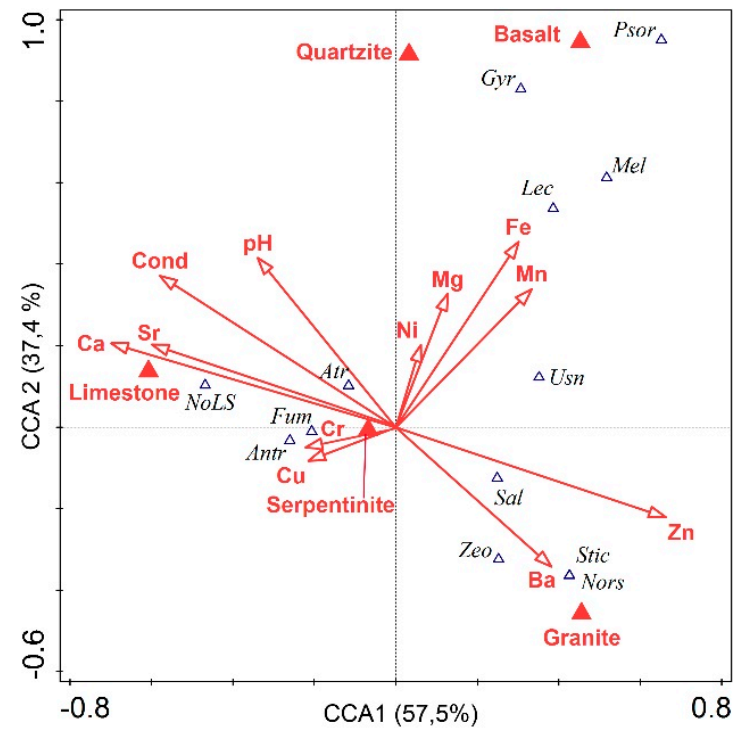

(a)

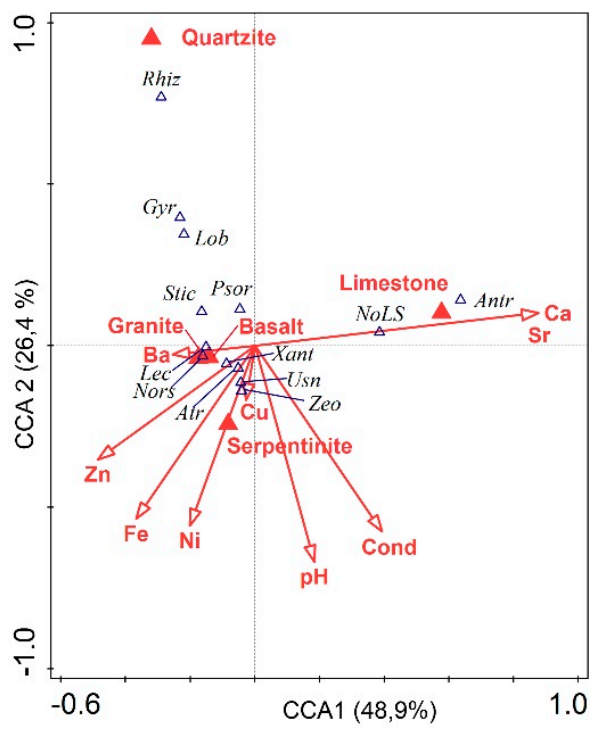

(b)

Figure 5. Canonical correspondence analysis (CCA) ordination plot showing the cover of lichens containing different secondary metabolites in relation to rock types and their chemical properties. (a) Foliose and fruticose species, (b) Crustose species. Abbreviations of names of the secondary metabolites include the first three or four letters. NoLS-no lichen substances. 
In crustose lichens, like in the group of foliose and fruticose lichens, the species with anthraquinones or lacking secondary metabolites had the highest cover on limestone with high Ca. Atranorin, usnic acid, xanthones and zeorin were associated mostly with serpentinites with a relatively high content of metals and pH. Similar habitats were selected by species with lecanoric and norstictic acids, but they were additionally found on basalt and granite with high Ba in the substrate. Lichens containing gyrophoric, lobaric and rhizocarpic acids were the most abundant on quartzite-a metal-poor substrate. Species with psoromic and stictic acids were common on quartzite but also found on granites and basalt where, like in the case of lecanoric and norstictic acids, their cover correlated with Ba in the substrate (Figure $5 b$ ).

\subsection{Secondary Metabolites and Environmental Parameters}

In the CCAs dealing with relationships between secondary metabolites and environmental parameters (Figure 6), the highest loading on CCA1 represent geographical position and elevation of the locality ( $57.5 \%$ and $48.0 \%$ of variance for foliose-fruticose and crustose species, respectively), while temperature and precipitation (for crustose species) have the highest loading on the CCA2.

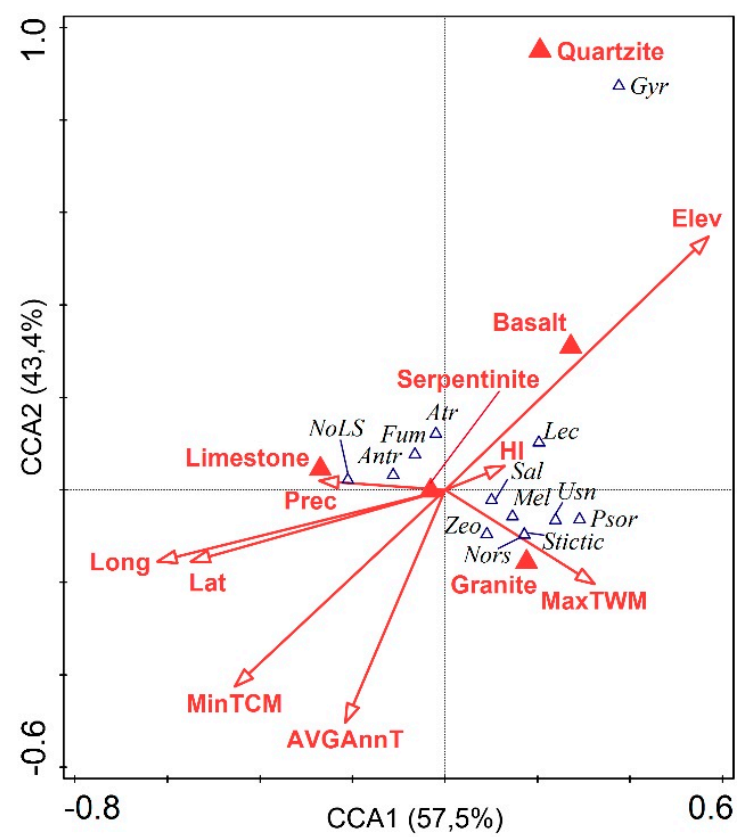

(a)

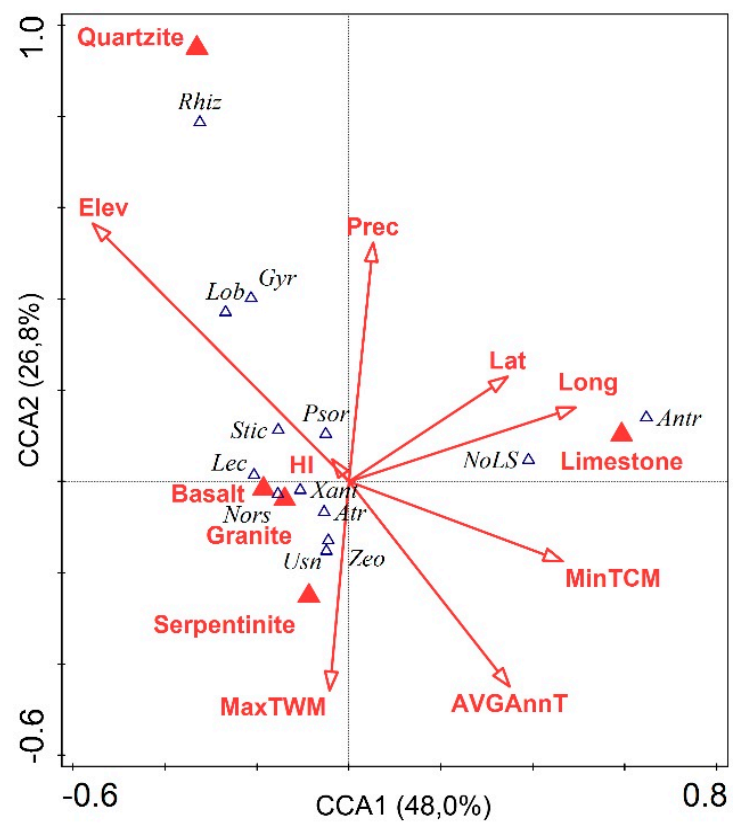

(b)

Figure 6. CCA ordination plot showing the cover of lichens containing different secondary metabolites in relation to climatic factors. (a) - Foliose and fruticose species, (b)-Crustose species. Abbreviations of names of the secondary metabolites include the first three or four letters. AVGAnnT-average annual temperature, Elev—elevation, Lat—latitude, Long—longitude, HI-heat index, MaxTWM-maximum temperature of the warmest month (July), MinTCM-minimum temperature of the coldest month (January), Prec-annual precipitation.

In the group of foliose-fruticose species (Figure 6a), lichen acids were separated into two groups depending on the variation of the maximum temperature of the warmest month. Melanins, psoromic, norstictic, salazinic, stictic, usnic acids and zeorin were found in species in summer-dry conditions while lichens with anthraquinones, atranorin, fumarprotocetraric acid or without lichen metabolites were usually more abundant in localities with higher precipitation and cooler summer. Gyrophoric acid was the only substance that was found primarily in high elevations on quartzite and to a lesser extent on basalt. 
Lichen acids in crustose lichens (Figure $6 \mathrm{~b}$ ) were subdivided into three groups depending on the climatic parameters of the habitat. Gyrophoric as well as rhizocarpic and lobaric acids and to some extent psoromic and stictic acids, had an affinity to high elevations and quartzites. Species with anthraquinones or without lichen metabolites were usually more abundant in the northernmost localities. Crustose lichens containing other metabolites show an affinity to rock type rather than the climatic conditions.

Interactive forward-selection analysis and the Monte-Carlo permutation test show that a type of rock substrate $(10 \%)$, latitude $(7 \%)$, elevation $(4.6 \%)$, average annual temperature $(2.5 \%)$, precipitation $(1.2 \%)$ and $\mathrm{Cr}$ in the substrate $(4.3 \%)$ have the highest explanatory effect on the chemistry of foliose and fruticose species. There is no statistical effect for $\mathrm{Ba}$ and $\mathrm{Fe}$ in the substrate as well as for $\mathrm{pH}$ and the heat index.

In the group of crustose species, the highest explanatory effects include $\mathrm{Sr}$ in the substrate $(9.2 \%)$, type of a rock substrate ( $8 \%), \mathrm{Co}$ and $\mathrm{Ni}$ ( 3 and $1.5 \%$, respectively) and elevation (2.8\%). There is no statistical effect for angle (aspect) and azimuth or $\mathrm{Cu}$ in the substrate.

\section{Discussion}

\subsection{Secondary Metabolite Diversity on Different Rocks}

The dependence of lichen secondary chemistry on rock types is evident when comparing the percentage of species containing different metabolites and inhabiting six rock types. Species growing on felsic, intermediate and mafic rocks (quartzites, granites and basalts) have a more diverse chemistry compared to species on ultramafic and carbonate substrates. A higher percentage of species on acidic and basic rocks contains secondary metabolites, a pattern that holds true for both life forms of lichens.

Crustose species, however, have the most intimate contact with their substrate, resulting in high levels of elemental accumulation [62]. Metal accumulation from the substrate in foliose and fruticose lichens is much lower and the metals are mostly restricted to the lowermost portions of thalli [63-65]. Taking into account these differences, we analyzed lichens of crustose and foliose-fruticose life forms separately.

Crustose lichens represented a statistically significant dependence of secondary chemistry on type of rock, while in foliose-fruticose taxa, these differences were seen only for species growing on chemically most distinct substrates-quartzites and limestones. This is evident not only in terms of the percentage of species containing secondary metabolites but also in the average number of secondary metabolites contained by a single species growing on different rock types, which increases from limestones to quartzites.

Three secondary metabolites, stictic and gyrophoric acids, as well as parietin, show a statistically significant change in their percentage in crustose lichens on different rock types. The species containing stictic and gyrophoric acids are more abundant on acidic substrates, while lichens with parietin are more common on limestone. These three metabolites may, hence, affect interactions of lichens with their substrates, while others may have different functions in lichen thalli.

\subsection{Chemical Properties of Rock Substrates}

The chemical properties of the different rocks are variable; however, the $\mathrm{pH}$ of rocks examined does not contribute to toxicity of lichen acids to lichens themselves [31,43]. Species inhabiting quartzite thrive in slightly acidic conditions with $\mathrm{pH}$ in the range of 6.16-6.68, which, however, is much higher than the $\mathrm{pH}$ of pine bark in the region, reaching a value as low as 3.85. In slightly acidic conditions, metals such as $\mathrm{Cu}, \mathrm{Fe}, \mathrm{Mn}$ and $\mathrm{Zn}$ are more bioavailable [66]; however, quartzite contained these elements in only trace quantities. $\mathrm{Ca}, \mathrm{Mg}$ and $\mathrm{P}$ have limited bioavailability under these conditions. As a result, lichens on quartzite survive in a nutrient-deficient environment. Granites with higher $\mathrm{pH}$ do not restrict the availability of phosphorus and contain more $\mathrm{Ca}, \mathrm{Fe}, \mathrm{Mn}$ and $\mathrm{Zn}$. Basalts, serpentinites and limestones have neutral to slightly alkaline conditions on their surface. Neutral pH is optimal for 
the availability of most nutrients except $\mathrm{Mn}$ but when the $\mathrm{pH}$ reaches $8, \mathrm{Fe}, \mathrm{Cu}$ and $\mathrm{B}$ become weakly available. Serpentinites and limestones are similar in $\mathrm{pH}$ and conductivity, resulting mostly from their high $\mathrm{Ca}$ and $\mathrm{Mg}$ in water extracts but have dramatically different content of other metals. Nickel and $\mathrm{Cr}$ have their highest concentrations in serpentinites, which are comparable to those found in serpentine soils of the region [67]. Lichens on serpentinites and limestones live in relatively concentrated ionic solutions dominated by $\mathrm{Mg}$ and $\mathrm{Ca}$ and no/minimal bioavailability of other nutrients.

\subsection{Secondary Metabolites and Chemistry of Rocks}

In crustose lichens, a group of species containing two major metabolites, gyrophoric and stictic acid and three less common metabolites, lobaric, psoromic and rhizocarpic acids, shows an affinity to substrates with low $\mathrm{pH}$ and a low content of metals. In the group of foliose and fruticose lichens three of these metabolites are common in species growing on substrates with high content of metals. Lichen substances, which have high affinity to metals, may act in two ways: they promote intracellular uptake of metals, thereby shaping the affinity of species to the substrates [68] or inactivate excess of metals in apoplast of thalli [69]. We assume that lichen substances in crustose lichens dominated in metal-poor conditions on quartzite (gyrophoric, stictic as well as lobaric, psoromic and rhizocarpic acids) may promote metal supply to lichens. Gyrophoric and psoromic acids are common in foliose species in metal-rich environments but they are contained in Rhizoplaca, Lasallia and Umbilicaria-the genera of umbilicate life forms-which make contact with the substrate only by a central umbilicus and may rely upon elements only from solutions. An ability to form complexes with $\mathrm{Cu}$ is shown for psoromic acid in lichens on cupriferous substrata [41]; however, gyrophoric acid does not form complexes with $\mathrm{U}, \mathrm{Cu}$ or Fe in Trapelia involuta (Taylor) Hertel [69].

Anthraquinones in all life forms, as well as fumarprotocetraric acid in fruticose species, are common substances in lichens on limestones and to some extent on serpentinites but minimal or lacking in rocks with high $\mathrm{Mg}$, Fe and Ni. Like atranorin in Cladonia species [68], these substances may promote absorption of nutrients in alkalic conditions, when they are poorly available to lichens. Lichens lacking secondary metabolites are similarly abundant on rocks with high $\mathrm{pH}$ and a low availability of elements other than $\mathrm{Ca}$ and $\mathrm{Mg}$. These are primarily gelatinous species of Collemataceae and Lichinaceae, which can uptake nutrients using polysaccharides or organic acids other than lichen secondary metabolites; however, this supposition needs to be experimentally tested.

Lichens with other secondary metabolites are the most abundant on rocks such as granite, basalt and serpentinite with higher concentrations of metals in the substrate. These are lecanoric, norstictic, usnic acids and zeorin. Their effect on shaping the lichen communities or in accumulation of metals is not evident. Thus, despite a high affinity to Fe shown in laboratory experiments [39] and to Cu in lichens on cupriferous substrata [40], species with norstictic acid do not show a higher accumulation rate compared to species containing no lichen acids [32]. Obligate iron-accumulating Acarospora species in the Acarospora smaragdula-group do not contain norstictic acid [70]. However, these metabolites may have a protective role against an excess of metals in the substrate.

\subsection{Secondary Metabolites and Climatic Factors}

This study shows that the abundance of species containing different lichen metabolites is affected by climate. Species with gyrophoric and lecanoric acids in all life forms, as well as lobaric, rhizocarpic, stictic and psoromic acids in crustose species are the most common in the highest elevations but this dependence is also influenced by substrate; they are more abundant on quartzite than on basalt at the same elevations. Species with anthraquinones or without lichen metabolites are usually more abundant in the northernmost but not elevated, localities with higher precipitation.

In the group of foliose-fruticose lichens, species containing the rest of the main metabolites, namely norstictic, usnic acids, melanins and zeorin, have an affinity to habitats with elevated summer temperatures. This is concordant with the finding that warming increases concentrations of usnic acid in thalli of Cladonia species [71] and that norstictic acid-containing Cetraria steppae (Savicz) Kärnefelt is 
restricted to warm temperate regions compared to species lacking this metabolite [72]. In the group of crustose lichens, species with the same metabolites group in accordance with their affinity to rock types and climatic parameters, however, their distribution is not influenced by these parameters compared to that of foliose species.

Our results reflect a range of possible relationships among lichen acids, rocks and climatic parameters. Some lichen metabolites may act as accumulation and retention agents for metals, active under a range of $\mathrm{pH}$. Apart from the protective role of lichen metabolites in the excess of light they may also be advantageous in adverse climatic conditions such as high summer temperatures along with prolonged drought which, in this continental region, are more important for lichens than low winter temperatures which affect terrestrial lichen distribution in Western Europe [73]. These findings suggest that the same metabolite may affect both accumulation of metals and protection against unfavorable conditions.

Author Contributions: Conceptualization, A.P.; methodology, A.P., S.E.F.-L., N.R.; software, A.P., S.E.F.-L.; investigation, A.P., A.T., M.M., E.K.; writing-original draft preparation, A.P.; writing-review and editing, N.R., C.B.; funding acquisition, A.P., A.T.

Funding: This research was funded by the Russian Foundation for Basic Research (grant 18-04-00414).

Acknowledgments: AT is grateful for Ministry of Science and Higher Education of the Russian Federation (agreement no. 02.A03.21.0006) for financial support. We would like to express our gratitude to anonymous reviewers whose valueable comments and meticulous reading allowed us to make substantial improvements of the manuscript.

Conflicts of Interest: The authors declare no conflict of interest.

\section{References}

1. Huneck, S.; Yoshimura, I. Identification of Lichen Substances; Springer: Berlin/Heidelberg, Germany, 1996; pp. 1-493.

2. Elix, J.A. A Catalogue of Standardized Chromatographic Data and Biosynthetic Relationships for Lichen Substances, 3rd ed.; Published by the author: Canberra, Australia, 2014; pp. 1-323.

3. Rundel, P.W. The ecological role of secondary lichen substances. Biochem. Syst. Ecol. 1978, 6, 157-170. [CrossRef]

4. Favero-Longo, S.E.; Piervittori, R. Lichen-plant interactions. J. Plant. Interact. 2010, 5, 163-177. [CrossRef]

5. Lawrey, J.D. Lichen secondary compounds: Evidence for a correspondence between antiherbivore and antimicrobial function. Bryologist 1989, 92, 326-328. [CrossRef]

6. Gauslaa, Y. Lichen palatability depends on investments in herbivore defence. Oecologia 2005, 143, 94-105. [CrossRef] [PubMed]

7. Lawrey, J.D. Biological role of lichen substances. Bryologist 1986, 89, 111-122. [CrossRef]

8. Vainshtein, E.A. The role of lichen substances in symbiosis. Bot. Zhurn. 1991, 76, 793-800.

9. Solhaug, K.A.; Gauslaa, Y. Parietin, a photoprotective secondary product of the lichen Xanthoria parietina. Oecologia 1996, 108, 412-418. [CrossRef]

10. Gauslaa, Y.; Solhaug, K.A. Fungal melanins as a sun screen for symbiotic green algae in the lichen Lobaria pulmonaria. Oecologia 2001, 126, 462-471. [CrossRef]

11. Prokopiev, I.A.; Poryadina, L.N.; Konoreva, L.A.; Chesnokov, S.V.; Shavarda, A.L. Variation in the composition of secondary metabolites in Flavocetraria lichens from Western Siberia. Russ. J. Ecol. 2018, 49, 401-405. [CrossRef]

12. Chowdhury, D.P.; Solhaug, K.A.; Gauslaa, Y. Ultraviolet radiation reduces lichen growth rates. Symbiosis 2017, 73, 27-34. [CrossRef]

13. MacGillivray, T; Helleur, R. Analysis of lichens under environmental stress using TMAH thermochemolysis-gas chromatography. J. Anal. Appl. Pyrolysis 2001, 58-59, 465-480. [CrossRef]

14. Øvstedal, D.O.; Lewis Smith, R.I. Lichens of Antarctica and South. Georgia: A Guide to Their Identification and Ecology; Cambridge University Press: Cambridge, UK, 2001; pp. 1-411. 
15. Luo, H.; Yamamoto, Y.; Kim, J.A.; Jung, J.S.; Koh, Y.J.; Hur, J.-S. Lecanoric acid, a secondary lichen substance with antioxidant properties from Umbilicaria antarctica in maritime Antarctica (King George Island). Polar Biol. 2009, 32, 1033-1040. [CrossRef]

16. Larsson, P.; Večeřová, K.; Cempírková, H.; Solhaug, K.A.; Gauslaa, Y. Does UV-B influence biomass growth in lichens deficient in sun-screening pigments? Environ. Exp. Bot. 2009, 67, 215-221. [CrossRef]

17. Bjerke, J.W.; Joly, D.; Nilsen, L.; Brossard, T. Spatial trends in usnic acid concentrations of the lichen Flavocetraria nivalis along local climatic gradients in the Arctic (Kongsfjorden, Svalbard). Polar Biol. 2004, 27, 409-417. [CrossRef]

18. Sheard, J.W. The comparative ecology and distribution and within-species variation of the lichenized Ascomycetes Ramalina cuspidata and R. siliquosa in the British Isles. Can. J. Bot. 1978, 56, 939-952. [CrossRef]

19. LaGreca, S. A Phylogenetic evaluation of the Ramalina americana chemotype complex (Lichenized Ascomycota, Ramalinaceae) based on rDNA ITS sequence data. Bryologist 2006, 102, 602-618. [CrossRef]

20. Culberson, C.F.; Culberson, W.L.; Arwood, D.A. Physiography and fumarprotocetraric acid production in the Cladonia chlorophaea group in North Carolina. Bryologist 1977, 80, 71-75. [CrossRef]

21. Renner, B. The presence or absence of secondary metabolites in cephalodia and their possible implications. J. Hattori Bot. Lab. 1982, 52, 367-377.

22. Renner, B.; Galloway, D.J. Phycosymbiodemes in Pseudocyphellaria in New Zealand. Mycotaxon 1982, 16, 197-231.

23. Boyle, A.P.; McCarthy, P.M.; Stewart, D. Geochemical control of saxicolous lichen communities on the creggaun gabbro, Letterfrack, Co. Galway, Western Ireland. Lichenologist 1987, 19, 307-317. [CrossRef]

24. Brodo, I.M. Substrate ecology. In The Lichens; Ahmadjian, V., Hale, M.E., Eds.; Academic Press: New York, NY, USA; London, UK, 1973; pp. 401-441.

25. Favero-Longo, S.E.; Isocrono, D.; Piervittori, R. Lichens and ultramafic rocks: A review. Lichenologist 2004, 36, 391-404. [CrossRef]

26. Favero-Longo, S.E.; Isocrono, D.; Piervittori, R. Measuring the biodiversity of saxicolous lichens above timberline with reference to environmental factors: The case of a Natura 2000 site of western Alps. Phytocoenologia 2009, 39, 51-78. [CrossRef]

27. Favero-Longo, S.E.; Matteucci, E.; Morando, M.; Rolfo, F.; Harris, T.B.; Piervittori, R. Metals and secondary metabolites in saxicolous lichen communities on ultramafic and non-ultramafic rocks of the Western Italian Alps. Aust. J. Bot. 2015, 63, 276-291. [CrossRef]

28. Purvis, O.W.; Halls, C. A review of lichens in metal-enriched environments. Lichenologist 1996, $28,571-601$. [CrossRef]

29. Rajakaruna, N.; Knudsen, K.; Fryday, A.M.; O’Dell, R.E.; Pope, N.; Olday, F.C.; Woolhouse, S. Investigation of the importance of rock chemistry for saxicolous lichen communities of the New Idria serpentinite mass, San Benito County, California, USA. Lichenologist 2012, 44, 695-714. [CrossRef]

30. Wirth, V. Die Silikatflechten-Gemeinschaften im ausseralpinen Zentraleuropa. Dissert. Bot. 1972, 17, 1-306.

31. Hauck, M.; Jürgens, S.R. Usnic acid controls the acidity tolerance of lichens. Environ. Pollut. 2008, 156, 115-122. [CrossRef] [PubMed]

32. Paukov, A.G.; Teptina, A.Y.; Pushkarev, E.V. Heavy metal uptake by chemically distinct lichens from Aspicilia spp. growing on ultramafic rocks. Aust. J. Bot. 2015, 63, 111-118. [CrossRef]

33. Ascaso, C.; Galvan, J.; Rodriguezpascual, C. The weathering of calcareous rocks by lichens. Pedobiologia 1982, 24, 219-229.

34. Jones, D.; Wilson, M.J.; Tait, J.M. Weathering of a basalt by Pertusaria corallina. Lichenologist 1980, 12, $277-290$. [CrossRef]

35. Wilson, M.J.; Jones, D.; McHardy, W.J. The weathering of serpentinite by Lecanora atra. Lichenologist 1981, 13, 167-176. [CrossRef]

36. Bačkor, M.; Fahselt, D. Using EDX-microanalysis and X-ray mapping to demonstrate metal uptake by lichens. Biologia (Bratislava) 2004, 59, 39-45.

37. Favero-Longo, S.E. Lichens on metal-rich substrates. In Plant Ecology and Evolution in Harsh Environments; Rajakaruna, N., Boyd, R.S., Harris, T.B., Eds.; Nova Science Publishers: New York, NY, USA, 2014; pp. 53-76.

38. Fortuna, L.; Baracchini, E.; Adami, G.; Tretiach, M. Melanization affects the content of selected elements in parmelioid lichens. J. Chem. Ecol. 2017, 43, 1086-1096. [CrossRef] [PubMed] 
39. Hauck, M.; Huneck, S.; Elix, J.A.; Paul, A. Does secondary chemistry enable lichens to grow on iron-rich substrates? Flora Morphol. Distrib. Funct. Ecol. Plants 2007, 202, 471-478. [CrossRef]

40. Purvis, O.W.; Elix, J.A.; Broomhead, J.A.; Jones, G.C. The occurrence of copper norstictic acid in lichens from cupriferous substrata. Lichenologist 1987, 19, 193-203. [CrossRef]

41. Purvis, O.W.; Elix, J.A.; Gaul, K.L. The occurrence of copper-psoromic acid in lichens from cupiferous substrata. Lichenologist 1990, 22, 345-354. [CrossRef]

42. Hauck, M.; Willenbruch, K.; Leuschner, C. Lichen substances prevent lichens from nutrient deficiency. J. Chem. Ecol. 2009, 35, 71-73. [CrossRef]

43. Hauck, M.; Jürgens, S.R.; Leuschner, C. Norstictic acid: Correlations between its physico-chemical characteristics and ecological preferences of lichens producing this depsidone. Environ. Exp. Bot. 2010, 68, 309-313. [CrossRef]

44. Nakajima, H.; Fujimoto, N.; Yamamoto, Y.; Amemiya, T.; Itoh, K. Response of secondary metabolites to $\mathrm{Cu}$ in the Cu-hyperaccumulator lichen Stereocaulon japonicum. Environ. Sci. Pollut. Res. 2019, 26, 905-912. [CrossRef]

45. Favero-Longo, S.E.; Matteucci, E.; Giordani, P.; Paukov, A.G.; Rajakaruna, N. Diversity and functional traits of lichens in ultramafic areas: A literature-based worldwide analysis integrated by field data at the regional scale. Ecol. Res. 2018, 33, 593-608. [CrossRef]

46. Gauslaa, Y.; Yemets, O.A.; Asplund, J.; Solhaug, K.A. Carbon based secondary compounds do not provide protection against heavy metal road pollutants in epiphytic macrolichens. Sci. Total Environ. 2016, 541, 795-801. [CrossRef] [PubMed]

47. Bačkorová, M.; Bil'ová, I.; Kimáková, T.; Bačkor, M. The presence of usnic acid does not protect the lichen Cladina arbuscula subsp. mitis against the long-term copper excess. S. Afr. J. Bot. 2015, 100, 94-100. [CrossRef]

48. Ogureeva, G.N.; Leonova, N.B.; Buldakova, E.V.; Kadetov, N.G.; Arkhipova, M.V.; Miklyaeva, I.M.; Bocharnikov, M.V.; Dudov, S.V.; Ignatova, E.A.; Ignatov, M.S.; et al. The Biomes of Russia-Map; WWF-Russia Conservation Strategy, Faculty of Geography Lomonosov Moscow State University: Moscow, Russia, 2018.

49. Pennino, M.G.; Paradinas, I.; Illian, J.B.; Muñoz, F.; Bellido, J.M.; López-Quílez, A.; Conesa, D. Accounting for preferential sampling in species distribution models. Ecol. Evol. 2019, 9, 653-663. [CrossRef] [PubMed]

50. Paukov, A.; Teptina, A. New records of lichens from Middle Urals, Russia. Folia Cryptog. Estonica 2012, 49, 39-43.

51. Paukov, A.G.; Gagarina, L.V.; Frolov, I.V. New and interesting lichen records from the Ural Mountains, Russia. Folia Cryptog. Estonica 2017, 54, 25-30. [CrossRef]

52. Urbanavichene, I.; Urbanavichus, G.; Mežaka, A.; Palice, Z. New records of lichens and lichenicolous fungi from the Southern Ural Mountains, Russia. II. Folia Cryptog. Estonica 2013, 50, 73-80. [CrossRef]

53. Nordin, A.; Moberg, R.; Tønsberg, T.; Vitikainen, O.; Dalsätt, Å.; Myrdal, M.; Snitting, D.; Ekman, S. Santesson's Checklist of Fennoscandian Lichen-forming and Lichenicolous Fungi. Ver. 29 April 2011. Available online: http://130.238.83.220/santesson/home.php (accessed on 30 March 2019).

54. Wijayawardene, N.N.; Hyde, K.D.; Lumbsch, H.T.; Liu, J.K.; Maharachchikumbura, S.S.N.; Ekanayaka, A.H.; Tian, Q.; Phookamsak, R. Outline of Ascomycota: 2017. Fungal Divers. 2018. [CrossRef]

55. Parker, K.C. Environmental relationships and vegetation associates of columnar cacti in the northern Sonoran Desert. Vegetatio 1988, 78, 125-140. [CrossRef]

56. Zelený, D.; Chytrý, M. Environmental control of the vegetation pattern in deep river valleys of the Bohemian Massif. Preslia 2007, 79, 205-222.

57. Diva-Gis. Available online: www.diva-gis.org (accessed on 7 January 2019).

58. Culberson, C.F.; Kristinsson, H.D. A standardized method for the identification of lichen products. J. Chromatogr. 1970, 46, 85-93. [CrossRef]

59. Orange, A.; James, P.W.; White, F.J. Microchemical Methods for the Identification of Lichens; British Lichen Society: London, UK, 2001; pp. 1-101.

60. Hammer, Ø.; Harper, D.A.T.; Ryan, P.D. PAST: Paleontological statistics software package for education and data analysis. Palaeont. Electr. 2001, 4, 1-9.

61. Šmilauer, P.; Lepš, J. Multivariate Analysis of Ecological Data Using CANOCO 5; Cambridge University Press: Padstow, UK, 2002; pp. 1-527.

62. Purvis, O.W. Adaptation and interaction of saxicolous crustose lichens with metals. Bot. Stud. 2014, 55, 1-14. [CrossRef] [PubMed] 
63. Goyal, R.; Seaward, M.R.D. Metal uptake in terricolous lichens. I. Metal localization within the thallus. New Phytol. 1981, 89, 631-645. [CrossRef]

64. Goyal, R.; Seaward, M.R.D. Metal uptake in terricolous lichens. III. Translocation in the thallus of Peltigera canina. New Phytol. 1982, 90, 85-98. [CrossRef]

65. Osyczka, P.; Rola, K.; Jankowska, K. Vertical concentration gradients of heavy metals in Cladonia lichens across different parts of thalli. Ecol. Indic. 2016, 61, 766-776. [CrossRef]

66. Lucas, R.E.; Davis, J.F. Relationships between $\mathrm{pH}$ values of organic soils and availabilities of 12 plant nutrients. Soil Sci. 1961, 92, 177-182. [CrossRef]

67. Teptina, A.; Paukov, A.; Rajakaruna, N. Ultramafic vegetation and soils in the circumboreal region of the Northern Hemisphere. Ecol. Res. 2018, 33, 609-628. [CrossRef]

68. Paul, A.; Hauck, M.; Leuschner, C. Iron and phosphate uptake explains the calcifuge-calcicole behavior of the terricolous lichens Cladonia furcata subsp. furcata and C. rangiformis. Plant Soil 2009, 319, 49-56. [CrossRef]

69. Kasama, T.; Murakami, T.; Ohnuki, T. Accumulation mechanisms of uranium, copper and iron by lichen Trapelia involuta. In Biomineralization (BIOM2001): Formation, Diversity, Evolution and Application, Proceedings of the 8th International Symposium on Biomineralization (September 25-28, 2001, Niigata, Japan), 2003; Kobayashi, I., Ozawa, H., Eds.; Tokai University Press: Kanagawa, Japan, 2003; pp. 298-301.

70. Wedin, M.; Westberg, M.; Crewe, A.T.; Tehler, A. Species delimitation and evolution of metal bioaccumulation in the lichenized Acarospora smaragdula (Ascomycota, Fungi) complex. Cladistics 2009, 25, 161-172. [CrossRef]

71. Asplund, J.; Siegenthaler, A.; Gauslaa, Y. Simulated global warming increases usnic acid but reduces perlatolic acid in the mat-forming terricolous lichen Cladonia stellaris. Lichenologist 2017, 49, 269-274. [CrossRef]

72. Lutsak, T.; Fernández-Mendoza, F.; Nadyeina, O.; Şenkardeşler, A.; Printzen, C. Testing the correlation between norstictic acid content and species evolution in the Cetraria aculeata group in Europe. Lichenologist 2017, 49, 39-56. [CrossRef]

73. Košuthová, A.; Svitková, I.; Pišút, I.; Senko, D.; Valachovič, M.; Zaniewski, P.T.; Hájek, M. Climatic gradients within temperate Europe and small-scale species composition of lichen-rich dry acidophilous Scots pine forests. Fungal Ecol. 2015, 14, 8-23. [CrossRef]

(C) 2019 by the authors. Licensee MDPI, Basel, Switzerland. This article is an open access article distributed under the terms and conditions of the Creative Commons Attribution (CC BY) license (http://creativecommons.org/licenses/by/4.0/). 